\title{
Vascular Dysfunction and Its Cardiovascular Consequences During and After COVID-19 Infection: A Narrative Review
}

\author{
Manisha Kar (D) \\ Department of Physiology, AllMS Bhubaneswar, Odisha, 751019, India \\ Correspondence: Manisha Kar, Department of Physiology, AllMS Bhubaneswar, Sijua, Patrapara, Bhubaneswar, Odisha, 75I019, India, \\ Tel +9l 9438884009, Email physio_manisha@aiimsbhubaneswar.edu.in
}

\begin{abstract}
The coronavirus disease 2019 (COVID-19) pandemic caused by severe acute respiratory coronavirus 2 (SARS-CoV2) has brought out changes in our daily life and has caused severe morbidity and mortality across the globe. Especially, post covid complications may remain a threat to the patient's life. It may also increase the burden on existing health infrastructure and the country's economy. This disease affects the respiratory system and other organ systems of the body, such as the cardiovascular system. The aim of the present narrative review is to understand how COVID-19 infection deranges vascular homeostasis, leading to endothelial dysfunction and arterial stiffness in the acute phase and following infection. To this effect, definite keywords were employed to obtain relevant information using PubMed database and Google Scholar search engines. It was documented that preexisting cardiovascular disease enhances morbidity in COVID-19 patients. Moreover, an elevated risk of development of new onset cardiovascular events has also been reported. Even a small amount of myocardial injury was significantly associated with death. The presence of virus in myocardial cells has also been documented. Furthermore, endothelial dysfunction and arterial stiffness were documented in the acute phase and 3-4 weeks to 4 months after COVID infection. The virus enters endothelial cells by binding with ACE2 "receptor" on its surface and deranges cellular machinery. It results in reduced conversion of Ang II to Ang (1-7). Accumulated Ang II then activates PI3K-Akt signaling pathway and regulates endothelial activation and production of IL-6 and reactive oxygen species (ROS). An imbalance between renin angiotensin aldosterone system (RAAS) and kallikrein kinin system (KKS) also occurs, which may cause endothelial dysfunction. It is understandable that the underlying pathophysiology of this altered arterial stiffness is multifactorial, involving various cellular and immunological biomolecules.
\end{abstract}

Keywords: arterial stiffness, endothelial dysfunction, COVID-19

\section{Introduction}

The emergence of the Corona virus disease 2019 (COVID-19) pandemic caused by severe acute respiratory corona virus 2 (SARS-CoV2) has changed the way the whole world used to live and carry out daily activities. It not only affects respiratory system, but also inflicts other organ systems of the body including cardiovascular system. It causes cardiovascular complications like heart failure, venous thromboembolism, cerebrovascular events. ${ }^{1}$ The endothelium is an integral part of the vascular conduit, essential for vascular homeostasis. Therefore, any perturbation of the vascular endothelial layer causes cardiovascular derangement. However, the data regarding vascular reactivity and arterial stiffness in COVID-19 infection is sparse. Most of the studies aimed to evaluate the arterial stiffness and endothelial function in the COVID patients during acute phase and following the infection. Furthermore, the investigators of few studies intended to understand the mechanism of vascular dysfunction in COVID-19 infection, which leads to cardiovascular complications. To this end, the present narrative review aims to understand how COVID-19 infection deranges vascular homeostasis, which eventually is reflected as endothelial dysfunction and arterial stiffness in acute phase and following infection. 


\section{Method}

The definite keywords used as search strategies to obtain relevant information were arterial stiffness, endothelial dysfunction, and COVID -19. The search engines used were PubMed database and Google Scholar. Total 27 articles have been found, inclusive of case report and reviews. Out of them, 15 articles have been discussed in the present narrative review. The overview of the research articles has been discussed in Table 1 .

\section{Endothelial Dysfunction, Arterial Stiffness, and Health Outcome}

Before understanding how COVID-19 infection disrupts vascular homeostasis, it is worth understanding the cardiovascular health outcome because of endothelial dysfunction and arterial stiffness. Conventionally the physiological indices for assessing vascular functions include assessment of arterial stiffness, pulse wave reflection, and endothelial function. ${ }^{2}$ Understandably, vascular conduit structural changes are more gradual than functional derangement. Therefore, functional assessment of vasculature is more sensitive than structural/morphological assessment during acute exposure of the disease process or risk factors affecting the vascular conduits. ${ }^{3}$ Clinical studies have revealed that there is an association between brachial-ankle pulse wave velocity (a marker of arterial stiffness) with the markers of inflammation, oxidative stress, and high sympathetic tone. ${ }^{4,5}$ An increase in arterial pulse wave velocity reflects an increase in arterial stiffness, culminating in an increase in summated forward and reflected pulse wave. The reflected pulse wave during the cardiac cycle increases afterload to the heart, thereby reducing the heart's stroke volume. It results in impairment of coronary arterial flow that eventually leads to ischemia of the heart generating arrhythmia and heart failure. ${ }^{6,7}$ Attenuating the cushioning effect of elastic arteries enhances the transmission of pulsatile energy to peripheral microcirculation, causing its damage. Therefore, the end organs with high blood flow such as brain and kidney may suffer from deterioration in its microcirculation. ${ }^{3}$ Ratchford et al (2021) reported that endothelial dysfunction and arterial stiffness can occur in young adults with COVID-19. ${ }^{8}$

\section{Role of Viral Infection in Endothelial Dysfunction and Arterial Stiffness}

In general, the viral infection may affect endothelium by various mechanisms and may lead to endothelial dysfunction. Several mechanisms are involved in this process, such as (1) viral infection leading to the inflammation may derange the function of renin-angiotensin system and enhances the production of reactive oxygen species, (2) viral infection directly increase the production of reactive oxygen species also, (3) it increases the synthesis of pro-inflammatory cytokines ie, interleukin-6, which may cause derangement of vascular tone, thereby may enhance functional arterial stiffness. Besides it, (4) activation of neutrophils leads to the release of various vasoactive substances such as prostanoids, lysosomal enzymes, and reactive oxygen species. Myeloperoxidases released from azurophil granules of neutrophils may attenuate NO bioavailability. Overall, these abnormalities may enhance endothelial dysfunction, thereby increasing functional arterial stiffness. ${ }^{3}$

\section{COVID-19 and Cardiovascular Dysfunction}

It has been previously mentioned that SARS-Cov2 also affects cardiovascular system besides its infliction on the respiratory system. Various clinical studies though few in number, reported it. It has been observed that the cardiovascular morbidity is more in those COVID patients who have a history of preexisting cardiovascular disease. ${ }^{9}$ Interestingly, an elevated risk of development of a new cardiovascular event has also been reported in COVID patients. Right and left diastolic dysfunction was reported in 39\% and $16 \%$ patients with COVID-19. ${ }^{10}$ This indicates the involvement of small vessels and capillaries. Interestingly, an increased level of troponin-I has been documented in a significant number of patients, associated with a worse prognosis. ${ }^{11}$ It was reported that even small amounts of myocardial injury (troponin I level $>0.03-0.09 \mathrm{ng} / \mathrm{mL}$ ) were significantly associated with death. ${ }^{12}$ Then the question arises what could be the reason behind this elevated serum level of troponin I. The reports indicate that it may be due to non-ischaemic myocarditis. Furthermore, observed diastolic dysfunction may also be attributed to non-ischemic myocarditis. ${ }^{13}$ In consecutive autopsies from COVID-19 patients, viral presence within the myocardium was documented. ${ }^{14}$ Moreover, the infected myocardium was infiltrated with a higher number of leukocytes. In the same study, higher expression of mRNA 


\begin{tabular}{|c|c|c|c|c|c|}
\hline $\begin{array}{l}\text { First Author } \\
\text { (Reference No.) }\end{array}$ & $\begin{array}{l}\text { Mean } \\
\text { Age }\end{array}$ & $\begin{array}{l}\text { Number of Cases and } \\
\text { Controls }\end{array}$ & Design & Methods for Assessment of Vascular Health & Outcomes Reported \\
\hline Nakano et al., $2021^{3}$ & & & & Narrative review & $\begin{array}{l}\text { ACE-2 receptor activity is inhibited in COVID-19, } \\
\text { thereby it affects vascular function. The study } \\
\text { suggested that pulse wave velocity (PWV) can be } \\
\text { employed to assess functional arterial stiffness } \\
\text { during acute phase of COVID-19 }\end{array}$ \\
\hline Ratchford et al., $2020^{8}$ & $\begin{array}{l}\text { Case - } \\
20.2 \pm 1.1 \\
\text { years } \\
\text { Control - } \\
23.0 \pm 1.3 \\
\text { years }\end{array}$ & $\begin{array}{l}\text { Case }-11 \\
\text { Control }-20\end{array}$ & $\begin{array}{l}\text { Cross- } \\
\text { sectional case } \\
\text { control }\end{array}$ & FMD in the arm and sPLM in the leg, cfPWV & $\begin{array}{l}\text { FMD was lower in SARS-CoV-2 group. sPLM was } \\
\text { lower in the SARS-CoV-2 group compared with the } \\
\text { control. cf PWV was higher in SARS-CoV- } 2 \text { group } \\
\text { than control group. }\end{array}$ \\
\hline Lala et al., $2020^{12}$ & $\begin{array}{l}\text { Median } \\
\text { age }-66.4 \\
\text { years }\end{array}$ & Case-2736, Non-survivor- 506 & $\begin{array}{l}\text { Cross- } \\
\text { sectional, } \\
\text { observational } \\
\text { study }\end{array}$ & $\begin{array}{l}\text { Demographics, medical histories, admission } \\
\text { laboratory results }\end{array}$ & $\begin{array}{l}\text { Small amounts of myocardial injury (troponin I } \\
>0.03-0.09 \mathrm{ng} / \mathrm{mL} \text { ) were significantly associated } \\
\text { with death, while greater amounts of troponin I } \\
>0.09 \mathrm{ng} / \mathrm{dl} \text { were significantly associated with higher } \\
\text { risk. }\end{array}$ \\
\hline Lindner et al., $2020^{14}$ & $\begin{array}{l}78-89 \\
\text { years }\end{array}$ & Consecutive autopsy cases- 39 & $\begin{array}{l}\text { Cross- } \\
\text { sectional, } \\
\text { observational } \\
\text { study }\end{array}$ & $\begin{array}{l}\text { Incidence of SARS-CoV-2 positivity in cardiac tissue } \\
\text { and CD } 3+, \text { CD } 45+\text {, and CD } 68+\text { cells in } \\
\text { myocardium and gene expression of tumor necrosis } \\
\text { growth factor } \alpha \text {, interferon } \gamma \text {, chemokine ligand } 5 \text {, } \\
\text { as well as interleukin- } 6,-8 \text {, and }-18\end{array}$ & $\begin{array}{l}\text { Viral presence within the myocardium was } \\
\text { documented. A response to this infection was } \\
\text { reported in cases with higher virus load. }\end{array}$ \\
\hline Judd et al., 2021 ${ }^{15}$ & $\begin{array}{l}\text { Case }-24 \\
\text { years }\end{array}$ & $\begin{array}{l}\text { I COVID-19 patient during } \\
\text { acute phase, but } \\
\text { asymptomatic }\end{array}$ & Case report & FMD, NMD, aortic PWV, Alx and clMT & $\begin{array}{l}\text { Decreased FMD and NMD in comparison to } \\
\text { reference values } \\
\text { No remarkable change in PWV }(5.9 \mathrm{~m} / \mathrm{s}) \text {, Alx ( } 27 \%) \\
\text { and cIMT } \\
\text { Decreased FMD } 6 \text { weeks after Covid-19 infection }\end{array}$ \\
\hline Nandadeva et al., $2021^{16}$ & $\begin{array}{l}23 \pm 3 \\
\text { years }\end{array}$ & $\begin{array}{l}\text { Case- } 16,4 \text { wk past } \\
\text { COVID-19 diagnosis [8- } \\
\text { aymptomatic (ASYMP), 8- } \\
\text { symptomatic (SYMP)] } \\
\text { Control- } 12\end{array}$ & Case control & FMD and reactive hyperemia, CVMR and cfPWV & $\begin{array}{l}\text { FMD was lower in SYM than ASYM and control } \\
\text { CVMR and arterial stiffness were not different } \\
\text { between any groups }\end{array}$ \\
\hline
\end{tabular}


Table I (Continued).

\begin{tabular}{|c|c|c|c|c|c|}
\hline $\begin{array}{l}\text { First Author } \\
\text { (Reference No.) }\end{array}$ & $\begin{array}{l}\text { Mean } \\
\text { Age }\end{array}$ & $\begin{array}{l}\text { Number of Cases and } \\
\text { Controls }\end{array}$ & Design & Methods for Assessment of Vascular Health & Outcomes Reported \\
\hline Schnaubelt et al., $2021^{17}$ & $\begin{array}{l}67-84 \\
\text { years }\end{array}$ & $\begin{array}{l}\text { Case- } 77 \\
\text { Control- } 22\end{array}$ & Case control & baPWV and cfPWV & $\begin{array}{l}\text { baPWV and cfPWV were higher in COVID-19 } \\
\text { patients than in controls. In multiple regression } \\
\text { analysis, COVID-19 was independently associated } \\
\text { with higher cfPWV and baPWV }\end{array}$ \\
\hline Szehgy et al., $2021^{18}$ & $\begin{array}{l}20 \pm 1 \\
\text { years }\end{array}$ & $\begin{array}{l}\text { Case }-15 \\
\text { Control- } 15\end{array}$ & $\begin{array}{l}\text { Cross- } \\
\text { sectional case } \\
\text { control }\end{array}$ & $\begin{array}{l}\text { Carotid stiffness, cIMT, aortic Alx and PWA } \\
\text { measurement }\end{array}$ & $\begin{array}{l}\text { Higher carotid artery stiffness, Young's modulus and } \\
\text { aortic stiffness ie, aortic Alx than control }\end{array}$ \\
\hline Rodilla et al., $2021^{19}$ & 67.5 years & $\begin{array}{l}\text { I2, I } 70 \text { patients admitted to } \\
\text { I50 Spanish } \\
\text { Centres included in the SEMI- } \\
\text { COVID- I } 9 \text { Network. ( } 2606 \\
\text { non-survivors, } 9564 \text { survivors) }\end{array}$ & $\begin{array}{l}\text { Observational, } \\
\text { retrospective, } \\
\text { multi-center } \\
\text { cohort study }\end{array}$ & Admission pulse pressure $\geq 60 \mathrm{~mm} \mathrm{Hg}$ & $\begin{array}{l}\text { Increased AS and systolic BP }<120 \mathrm{~mm} \mathrm{Hg} \\
\text { significantly and independently predicted all-cause } \\
\text { in-hospital mortality (odds ratio: } \mathrm{I} .27, P=0.000 \mathrm{I} \text { ) }\end{array}$ \\
\hline Kumar et al., $2021^{20}$ & - & $\begin{array}{l}23 \text { Mild, } 21 \text { Moderate and } 20 \\
\text { Severe COVID-19 patients }\end{array}$ & $\begin{array}{l}\text { Prospective } \\
\text { non- } \\
\text { randomized } \\
\text { observational } \\
\text { study }\end{array}$ & cfPWV, ANI_cfPWV & $\begin{array}{l}\text { cfPWV was significantly lower in mild patients than } \\
\text { both moderate and severe patients. ANI_cfPWV in } \\
\text { moderate and severe patients was significantly } \\
\text { higher than mild patients. }\end{array}$ \\
\hline Lambadiari et al., $2021^{21}$ & $>18$ years & $\begin{array}{l}\text { Cases-70 four months after } \\
\text { COVID-19 infection, positive } \\
\text { control-70 untreated } \\
\text { hypertensive patients, Healthy } \\
\text { control-70 }\end{array}$ & $\begin{array}{l}\text { Case-control } \\
\text { prospective } \\
\text { study }\end{array}$ & $\begin{array}{l}\text { PBR of the sublingual arterial microvessels, FMD, } \\
\text { CFR, PWV, global LV and RV GLS, serum MDA, } \\
\text { thrombomodulin and vWF levels }\end{array}$ & $\begin{array}{l}\text { COVID-19 patients had similar CFR and FMD with } \\
\text { hypertensives but lower values than controls. } \\
\text { Compared to controls, both COVID-19 and } \\
\text { hypertensives had greater PBR, higher PWV and } \\
\text { impaired LV and RV GLS. MDA and } \\
\text { thrombomodulin were higher in COVID-19 } \\
\text { patients than both hypertensives and controls. }\end{array}$ \\
\hline $\begin{array}{l}\text { Stamatelopoulos et al., } \\
2021^{22}\end{array}$ & $\begin{array}{l}55-87 \\
\text { years }\end{array}$ & $\begin{array}{l}\text { Case- } 1671 \\
\text { Control- } 934\end{array}$ & $\begin{array}{l}\text { Retrospective, } \\
\text { longitudinal } \\
\text { cohort study }\end{array}$ & $\begin{array}{l}\text { ePWV was calculated using age and MBP (derived } \\
\text { from cfPWV data) }\end{array}$ & $\begin{array}{l}\text { Calculation of ePWV, a readily applicable estimation } \\
\text { of arterial stiffness and it may serve as an additional } \\
\text { clinical tool to refine risk stratification beyond } \\
\text { established risk scores }\end{array}$ \\
\hline Aydin et al., $2021^{23}$ & $\begin{array}{l}65.7 \pm \\
10.7 \text { years }\end{array}$ & $\begin{array}{l}\text { Case- } 65 \\
\text { Control-50 }\end{array}$ & $\begin{array}{l}\text { Prospective } \\
\text { case control } \\
\text { study }\end{array}$ & $\begin{array}{l}\text { Systolic and diastolic blood pressure, urea, } \\
\text { creatinine, eGFR at admission, serum lipid profile, } \\
\text { BMI, CAVI, and ABPI }\end{array}$ & $\begin{array}{l}\text { Right and left cardio-ankle vascular index values } \\
\text { were increased in COVID-19 patients which was } \\
\text { thought to be prognostically significant }\end{array}$ \\
\hline
\end{tabular}




\begin{tabular}{|c|c|c|c|c|c|}
\hline Judd P et al., 202 I $^{24}$ & $>18$ years & $\begin{array}{l}\text { Case }-14 \\
\text { Healthy control- } 14 \\
\text { ASCVD control cohort - } 14\end{array}$ & $\begin{array}{l}\text { Cross- } \\
\text { sectional, } \\
\text { observational } \\
\text { study }\end{array}$ & $\begin{array}{l}\text { FMD, NMD, PWV, Alx, IMT, compounds of arginine } \\
\text { and kynurenine } \\
\text { metabolism, homocysteine, vWF, EMP, } \\
\text { antiendothelial cell antibodies, inflammatory, and } \\
\text { immunological parameters, as well as nailfold } \\
\text { capillary morphology }\end{array}$ & $\begin{array}{l}\text { FMD and NMD (parameters of endothelial } \\
\text { dysfunction) and inflammation were altered in post- } \\
\text { COVID-19 patients }\end{array}$ \\
\hline $\begin{array}{l}\text { Bruno et al, 202I } \\
\text { [Covid-19 effects on } \\
\text { ARTErial Stlffness and } \\
\text { vascular AgeiNg } \\
\text { (CARTESIAN) study] }\end{array}$ & $\begin{array}{l}\text { Not } \\
\text { mentioned }\end{array}$ & $\begin{array}{l}\text { Group I-3 } \\
\text { Patients tested for SARS-CoV- } \\
2 \text { requiring } \\
\text { I.hospitalization in intensive } \\
\text { care unit } \\
\text { 2.hospitalization in medical } \\
\text { ward } \\
\text { 3.no hospitalization } \\
\text { Group } 4 \\
\text { Patients tested negative and } \\
\text { presenting at Emergency } \\
\text { department }\end{array}$ & $\begin{array}{l}\text { Case control, } \\
\text { longitudinal, } \\
\text { multicentric } \\
\text { study }\end{array}$ & $\begin{array}{l}\text { Mandatory - cf PWV, brachial blood pressure, } \\
\text { central blood pressure, carotid ultrasound, brachial } \\
\text { FMD, Recommended - cardiac ultrasound, } 24 \mathrm{~h} \\
\text { blood pressure, thoracic aortic calcification }\end{array}$ & $\begin{array}{l}\text { "At the time of writing ( } 10 \text { November 2020), } 43 \\
\text { centres from } 2 \text { I countries had expressed interest in } \\
\text { participating with a total expected number of } \\
>2500 \text { included patients." }\end{array}$ \\
\hline
\end{tabular}

Abbreviations: FMD, flow-mediated dilation; NMD, nitroglycerin-mediated dilation; PWV, aortic pulse wave velocity; Aix, augmentation index; clMT, carotid intima-media-thickness; CVMR, cerebral vasomotor reactivity to hypercapnia; cfPWV, carotid-femoral pulse wave velocity; baPWV, brachial ankle pulse wave; PWA, pulse wave analysis; sPLM, single passive limb movement; AS, arterial stiffness; ANI_cfPWV, age-normalized increase in cfPWV; CFR, coronary flow reserve; PBR, perfused boundary region; GLS, global left (LV) and right (RV) ventricular longitudinal strain; MDA, malondialdehyde; vWF, von Willebrand factor; ePWV, estimated pulse wave velocity; CAVI, cardio-ankle vascular index; ABPI, ankle-brachial pressure index; vWF, von Willebrand factor; EMP, endothelial microparticles. 
transcripts of pro-inflammatory genes was also reported in infected myocardium. ${ }^{14}$ It was observed that the stoppage of ACE2 inhibitor in COVID-positive patients caused an increase in cardiac afterload because of increased blood pressure and /or arterial stiffness. Enhanced cardiac afterload then leads to impaired myocardial circulation. ${ }^{3}$ Overall, these pathophysiological mechanisms along with myocardial injury due to hypoxaemia and severe respiratory failure may lead to increased mortality in patients with COVID-19. ${ }^{3}$

It was reported that in a young, COVID-19 patient without any associated cardiovascular morbidity, FMD and NMD were decreased in comparison to reference values. This decreased FMD value persisted even after 6 weeks of infection. ${ }^{15}$ In another case-control study, significant decrease of FMD value was demonstrated in symptomatic, young adults even after acute phase of disease (more than 4 weeks from diagnosis). However, there was no significant difference of cerebro vasomotor reactivity to hypercapnia (CVMR) and arterial stiffness observed between groups. ${ }^{16}$ This is suggestive of the persistent effect of COVID-19 infection on vascular function even after acute phase of COVID-19. Interestingly, in a case-control study, brachial-ankle pulse wave velocity (baPWV) and carotid-femoral pulse wave velocity (cfPWV) were significantly higher in COVID-19 patients than in control. Furthermore, multiple regression analysis revealed COVID-19 was independently associated with baPWV and cfPWV. ${ }^{17}$ Moreover, carotid artery stiffness and aortic augmentation index were found to be higher in young adults 3-4 weeks after being COVID positive than control. ${ }^{18}$ In another casecontrol study, FMD and single passive leg movement (sPLM) -related blood flow was lower in the COVID patients 3-4 weeks after testing positive than control, but cfPWV was higher in the study group. ${ }^{8}$ Rodilla et al (2021) reported that increased arterial stiffness and systolic BP $<120 \mathrm{~mm}$ Hg significantly and independently can predict all-cause in-hospital mortality. ${ }^{19}$ It was documented that cfPWV was significantly lower in mild COVID patients than both moderate and severe patients. Age-Normalized increase in cfPWV (ANI_cfPWV) in moderate and severe patients was significantly higher than mild patients. ${ }^{20}$ Lambadiari et al (2021) reported that 4 months after COVID-19 infection, COVID-19 patients had similar coronary flow reserve (CFR) and FMD with hypertensives but lower values than controls. Moreover, both COVID patients and hypertensives had higher PWV. Serum markers of oxidative stress i.e; malondialdehyde and endothelial function (thrombomodulin), were higher in COVID patients. ${ }^{21}$ In a retrospective longitudinal cohort study, estimated pulse wave velocity (ePWV) has been calculated using age and mean blood pressure (MBP) [derived from cfPWV data] and the study has concluded that calculation of ePWV, may serve as an additional clinical tool to refine risk stratification of hospitalized patients with COVID-19 besides already established risk factors and scores. ${ }^{22}$ A prospective, case-control study reported that right and left cardio-ankle vascular index values (one of the non-invasive surrogate markers of the arterial stiffness) were more in COVID-19 patients and have a prognostically significance. ${ }^{23}$ Another cross-sectional, observational study reiterated the previous findings i.e; most of the parameters of endothelial dysfunction (FMD, NMD) and inflammatory vasculopathy were altered in COVID patients. ${ }^{24} \mathrm{~A}$ multicentric, case-control, longitudinal study entitled "Covid-19 effects on ARTErial StIffness and vascular AgeiNg (CARTESIAN) study" has been designed, which is being conducted in 43 centres from 21 countries involving $>2500$ COVID patients. The broader objective of this study is to evaluate the presence of Early Vascular Ageing (EVA) 6 and 12 months after COVID-19 infection. Estimation of cfPWV, brachial blood pressure, central blood pressure, carotid ultrasound, brachial FMD are employed mandatorily and cardiac ultrasound, $24 \mathrm{~h}$ blood pressure, thoracic aortic calcification are being recommended. ${ }^{25}$

\section{The Pathophysiological Mechanism of Endothelial Dysfunction and Arterial Stiffness in COVID-19}

The clinical studies suggested various pathophysiological mechanisms underlying increased arterial stiffness in COVIDpositive patients. One such mechanism is indirect endothelial damage because of acute inflammatory response and release of a plethora of cytokines in response to SARS COVID-19 infection. Expression of ACE2 has been particularly detected on arterial smooth muscle cells and both arterial and venous endothelial cells. ${ }^{18}$ The spike-glycoproteins of SARS CoV-2 virus binds with ACE2, thereby using it as its portal to enter the cell and replicates within the cell. It results in down-regulated expression of ACE2 and the cell surface trans-membrane protease serine 2 (TMPRSS2). ${ }^{26}$ Consequently, the conversion of Ang II to Ang (1-7) is reduced and Ang II accumulates within the cell. Ang II is a 
known potent vasoconstrictor. However, excessive accumulation of it activates PI3K-Akt signaling pathway through AT1 receptor and thereby regulate endothelial activation and production of IL-6 and ROS. ${ }^{27}$ Loss of ACE2 leads to imbalance of renin-angiotensin-aldosterone system (RAAS) and the kallikrein-kinin system (KKS). Activated KKS then may cause endothelial dysfunction, which may promote enhanced leukocyte adhesion, complement activation. ${ }^{27}$ The resulting endothelial dysfunction may affect vascular tone and its permeability also. Vascular endothelial damage may lead to platelet aggregation and blood coagulation. It also enhances the synthesis and secretion of pro-inflammatory cytokines (cytokine storm) such as IL-2, IL-7, IL-10, MCP-1, TNF $\alpha$ from adjoining tissues and blood mononuclear cells. ${ }^{28}$ This infection may cause decrease in $\mathrm{CD} 4^{+}$and $\mathrm{CD} 8^{+} \mathrm{T}$ cell count as well as IFN- $\gamma$ induced $\mathrm{CD} 4^{+} \mathrm{T}$ cell production, which might be correlated with disease severity. ${ }^{28}$ The pro-coagulant and pro-inflammatory nature of blood may increase the risk of plaque rupture and thromboembolism, which eventually leads to myocardial infarction. It provides an additional evidence for detrimental effects of SARS-CoV-2 on young, adult vasculature. ${ }^{17}$ Besides it, damaged endothelial cells promote hypercoagulable state, which also dysregulates normal vascular tone. ${ }^{18}$ The endothelium is not just a mere barrier. It is comprehensible that endothelial cells have location specific functional specializations and activation status. Accumulating pieces of evidence point towards the role of endothelial cells in maintenance of immunological homeostasis. ${ }^{29}$ It also acts as a sensor to immunological threat which may be of viral origin. It was also demonstrated that serum level of E-selectin and angiopoietin-2, considered to be as circulating biomarker of perturbation of endothelial function, were also highly increased in a cohort of COVID positive patients and it was associated with the degree of severity of the disease process. ${ }^{29}$ Understandably, the endothelial cells get activated from bio-signals emanated from the infected tissue or from the virus. It induces a pro-adhesive and chemokine-secreting phenotype of endothelial cells, which in turn helps in the recruitment of circulating blood cell and becomes instrumental in producing "cytokine storm". ${ }^{30}$ This "cytokine storm" further perturbs endothelial functionality and enhances arterial stiffness. Therefore, it may be concluded that the role of vascular endothelial cells is pivotal in maintaining vascular homeostasis. Severe systemic inflammation also brings about changes in hormonal balance, maintaining vascular tone. It also causes vascular adrenoceptor hyporeactivity, decreased level of endogenous vasopressin, and corticosteroid insufficiency. Altogether these may reduce vascular tone and may affect arterial stiffness. ${ }^{31}$

\section{Conclusion}

The coronavirus disease 2019 (COVID-19) pandemic caused by severe acute respiratory coronavirus 2 (SARS-CoV2) has caused severe morbidity and mortality across the globe. Especially, post-covid complications may remain a threat to the patient's life. Though the symptoms reported are mainly respiratory in origin, other organ systems are also affected by this virus, such as the cardiovascular system. The preexisting cardiovascular disease enhances the morbidity due to COVID-19. However, newly onset cardiovascular event has also been reported in COVID-positive patients. The endothelium is an integral part of vascular conduit and is essential for vascular homeostasis. Any perturbation of the vascular endothelium may cause cardiovascular derangement, which has been reported in COVID-positive patients as assessed by the altered parameters of arterial stiffness such as pulse wave velocity, aortic augmentation index, and flowmediated vasodilatation. The underlying pathophysiology of this altered arterial stiffness is multifactorial involving various cellular and immunological biomolecules.

\section{Disclosure}

The author reports no conflicts of interest in this work.

\section{References}

1. Figliozzi S, Masci PG, Ahmadi N, et al. Predictors of adverse prognosis in COVID-19: a systematic review and meta-analysis. Eur J Clin Invest. 2020;50(10):e13362. doi:10.1111/eci.13362

2. Tanaka A, Tomiyama H, Maruhashi T, et al. Physiological Diagnostic Criteria for Vascular Failure. Hypertension. 2018;72:1060-1071.

3. Nakano H, Shiina K, Tomiyama H. Cardiovascular Outcomes in the Acute Phase of COVID-19. Int J Mol Sci. 2021;22:4071-4083.

4. Kim M, Yoo HJ, Kim M, et al. Associations among oxidative stress, Lp-PLA2 activity and arterial stiffness according to blood pressure status at a 3.5-year follow-up in subjects with prehypertension. Atherosclerosis. 2017;257:179-185. 
5. Tomiyama H, Shiina K, Vlachopoulos C, et al. Involvement of Arterial Stiffness and Inflammation in Hyperuricemia-Related Development of Hypertension. Hypertension. 2018;72:739-745.

6. Fukuda D, Yoshiyama M, Shimada K, et al. Relation between aortic stiffness and coronary flow reserve in patients with coronary artery disease. Heart. 2006;92:759-762.

7. Chirinos JA, Kips JG, Jacobs DR, et al. Arterial wave reflections and incident cardiovascular events and heart failure: mesa (Multiethnic Study of Atherosclerosis). J Am Coll Cardiol. 2012;60:2170-2177.

8. Ratchford SM, Stickford JL, Province VM, et al. Vascular alterations among young adults with SARS-CoV-2. Am J Physiol Heart Circ Physiol. 2021;320:H404- H410.

9. Ejaz H, Alshrani A, Zafar A, et al. COVID-19 and comorbidities: deleterious impact on infected patients. J Infect Public Health. 2020;13 (12):1833-1839.

10. Szekely Y, Lichter Y, Taieb P, et al. Spectrum of cardiac manifestations in COVID-19 - a systematic echocardiographic study. Circulation. 2020;142(4):342-353. doi:10.1161/CIRCULATIONAHA.120.047971

11. Zhou F, Yu T, Du R, et al. Clinical course and risk factors for mortality of adult inpatients with COVID-19 in Wuhan, China: a retrospective cohort study. Lancet. 2020;395(10229):1054-1062. doi:10.1016/S0140-6736(20)30566-3

12. Lala A, Johnson KW, Januzzi JL, et al. Prevalence and Impact of Myocardial Injury in Patients Hospitalized With COVID-19 Infection. J Am Coll Cardiol. 2020;76:533-546.

13. Grimaud M, Starck J, Levy M, et al. Acute myocarditis and multisystem inflammatory emerging disease following SARS-CoV-2 infection in critically ill children. Ann Intensive Care. 2020;10:69.

14. Lindner D, Fitzek A, Brauninger H, et al. Association of cardiac infection with SARS-CoV-2 in confirmed COVID-19 autopsy cases. JAMA Cardiol. 2020;5:1281-1285.

15. Judd P, Kessler HH, Brodmann M. Case Report: changes of vascular reactivity and arterial stiffness in a patient with Covid-19 infection. Front Cardiovasc Med. 2021;8:671669.

16. Nandadeva D, Young BE, Stephens BY, et al. Blunted peripheral but not cerebral vasodilator function in young otherwise healthy adults with persistent symptoms following COVID-19. Am J Physiol Circ Physiol. 2021;321:H479-H484.

17. Schnaubelt S, Oppenauer J, Tihanyi D, et al. Arterial stiffness in acute COVID-19 and potential associations with clinical outcome. $J$ of Int Med. 2021. doi:10.1111/joim. 13275

18. Szeghy RE, Province VM, Stute NL, et al. Carotid stiffness, intima-media thickness and aortic augmentation index among adults with SARS-CoV-2. Exp Physiol. 2021;2:1-14.

19. Rodilla E, López-Carmona MD, Cortes X, et al. SEMI-COVID-19 network. impact of arterial stiffness on all-cause mortality in patients hospitalized with COVID-19 in Spain. Hypertension. 2021;77:856-867.

20. Kumar N, Kumar S, Kumar A, et al. The COSEVAST Study Outcome: evidence of COVID-19 severity proportionate to surge in arterial stiffness. Indian J Crit Care Med. 2021;25:1113-1119.

21. Lambadiari V, Mitrakou A, Kountouri A, et al. Association of COVID-19 with impaired endothelial glycocalyx, vascular function and myocardial deformation 4 months after infection. Eur J of Heart Failure. 2021;23:1916-1926.

22. Stamatelopoulos K, Georgiopoulos G, Baker KF, et al. Estimated pulse wave velocity improves risk stratification for all-cause mortality in patients with CIVID-19. Sci Rep. 2021;11:20239.

23. Aydin E, Kant A, Yilmaz G. Evaluation of the cardio-ankle vascular index in COVID-19 patients. Rev Assoc Med Bras. 2021;13:S010442302021005012202.

24. Judd P, Gressenberger P, Muster V, et al. Evaluation of endothelial dysfunction and inflammatory vasculopathy after SARS-CoV-2 infection-A cross sectional study. Front Cardiovasc Med. 2021;8:750887. doi:10.3389/fcvm.2021.750887

25. Bruno RM, Spronck B, Hametner B, et al. Covid-19 effects on ARTErial Stiffness and vascular AgeiNg: CARTESIAN Study Rationale and Protocol. Artery Res. 2021;27:59-68.

26. Pirzada A, Mokhtar AT, Moeller AD. COVID-19 and myocarditis: what do we know so far? C J C Open. 2020;2:278-285.

27. Gavriilaki E, Anyfanti P, Gavriilaki M, Lazaridis A, Douma S, Gkaliagkousi E. Endothelial Dysfunction in COVID-19: lessons learned from Coronaviruses. Curr Hypertens Rep. 2020;22:63-75.

28. Chen G, Wu D, Guo W, et al. Clinical and immunological features of severe and moderate coronavirus disease 2019. J Clin Investig. 2020;130:2620-2629.

29. Degauque N, Haziot B, Mooney N. Endothelial cell, myeloid and adaptive immune responses in SARS-CoV-2 infection. THE FASEB J. 2021;35: e21577.

30. Davignon J, Granz P. Role of endothelial dysfunction in atherosclerosis. Circulation. 2004;109:III27-32.

31. Pleiner J, Heere-Ress E, Langenberger H, et al. Adrenoceptor hyporeactivity is responsible for Escherichia coli endotoxin-induced acute vascular dysfunction in humans. Arterioscler Thromb Vasc Biol. 2002;22:95-100.

Vascular Health and Risk Management

\section{Dovepress}

\section{Publish your work in this journal}

Vascular Health and Risk Management is an international, peer-reviewed journal of therapeutics and risk management, focusing on concise rapid reporting of clinical studies on the processes involved in the maintenance of vascular health; the monitoring, prevention and treatment of vascular disease and its sequelae; and the involvement of metabolic disorders, particularly diabetes. This journal is indexed on PubMed Central and MedLine. The manuscript management system is completely online and includes a very quick and fair peer-review system, which is all easy to use. Visit http://www.dovepress.com/testimonials.php to read real quotes from published authors.

Submit your manuscript here: https://www.dovepress.com/vascular-health-and-risk-management-journal 